\title{
Scholarly Impact: a Bibliometric and Altmetric study of the Journal of Community Informatics
}

\begin{tabular}{cl}
\hline Filistea Naude & $\begin{array}{l}\text { University of South Africa, South Africa } \\
\text { Corresponding Author. } \\
\text { fnaude@unisa.ac.za }\end{array}$ \\
Judy van Biljon & University of South Africa, South Africa \\
& $\underline{\text { vbilja@,unisa.ac.za }}$ \\
\end{tabular}

Demonstrating scholarly impact is a matter of growing importance. This paper reports on a bibliometric and altmetric analysis conducted on the Journal of Community Informatics (JOCI). Besides the bibliometric analysis the study also looked into JOCI article-level metrics by comparing usage metrics (article views), alternative metrics (Mendeley readership), and traditional citation metrics (Google Scholar citations). The main contribution is to provide more insight into the metrics that could influence the citation impact in Community Informatics research. Furthermore, the study used articlelevel metrics data to identify, compare and rank the most impactful papers published in JOCI over a 12-year period.

\section{Introduction}

Community Informatics (CI) is the use of Information and Communication Technologies (ICT) to enable and empower the community as a complex sociological phenomenon (Stillman \& Linger, 2009). In this convergence of the community with information sciences and technologies, it integrates the oldest social institution of human kind with the newest frontiers of material society (Carroll, Shih \& Kropczynski, 2015). Community Informatics, as interdisciplinary research, presents challenges to professional librarians and scholars who aim to characterise and delineate the subject area (Less, 2008). This can negatively affect research impact as measured by citation

Naude, F., van Biljon, J. (2017). Scholarly impact: a bibliometrics and altmetric study of the Journal of Community Informatics. The Journal of Community Informatics, 13(1), 152-175.

Date submitted: 2017-03-01. Date accepted: 2017-03-18.

Copyright (C), 2017 (the authors as stated). Licensed under the Creative Commons AttributionNonCommercial-ShareAlike 2.5. Available at: www.ci-journal.net/index.php/ciej/article/view/1378 
indexes. Global academic literature remains dominated by northern hemisphere research and developed-world models that do not always take into account the specific sociopolitical environment of the developing regions (Alperin, 2015; Neylon et al., 2013) and the challenges faced by researchers from developing and emerging economies (using the characteristics proposed by Roztocki and Weistroffer (2011) to distinguish between developed, emerging, and developing economies).

The global political environment requires transparency, accountability, and demonstrable return-from-investment, and tertiary education institutions are under increasing pressure to provide evidence of the value of the services they provide (Neylon et al., 2013; Von Solms \& Von Solms, 2016). The term impact is generally agreed to refer to the effect of research beyond academia and captures the idea that there are a range of impacts of different types, which may be of different levels of importance to various stakeholders (Neylon et al., 2013). The measuring of research impact is contested (Bornmann, 2014); the criteria include the quality of the research outputs, funding associated with research outputs and the related citations (Neylon et al., 2013; Von Solms \& Von Solms, 2016) as measured by bibliometrics and alternative metrics (Bornmann, 2014). Therefore, publishing research outputs and being cited are some of the premier demonstrations of academic success, both to the researchers and sponsoring institutions involved. The CI researcher, like all other researchers, is subjected to performance evaluation measures for the purpose of appointment, promotion, and awarding of grants and research incentives. Against the background of the interdisciplinary CI landscape and the mounting pressure to show research impact, the research question guiding this study is: What research metrics should be considered in supporting CI research impact?

As noted, the concept of research impact is contested. However, a wider discussion of research impact is beyond the scope of this study, which will conclude with the definition of research outputs making impact when they are read, used and/or cited (Von Solms \& Von Solms, 2016). The impact of research is assessed by using qualitative measures (peer review) and supplemented with quantitative measures (bibliometric indicators and citation-based metrics). Agarwal et al. (2016: 297) defines bibliometrics as "the process of extracting measureable data through statistical analysis of published research studies and how the knowledge within a publication is used". It is a method to systematically count the number of publications within a discipline. More recently altmetrics (alternative to citation metrics) measures are steadily gaining ground in the global political environment, and research institutions are under increasing pressure to provide evidence of not only scholarly but also societal impact of the research (Bornmann, 2014; Neylon et al., 2013). Altmetrics (also referred to as social media metrics) measure scholarly performance of individual articles based on engagement of scholars and the public with research articles in an online and social media environment (Lin \& Fenner, 2013).

In general, three types of research outlets are currently available to disseminate such research outputs, namely journals, conference proceedings, and books. Alternative metrics hold the promise of developing indicators for measuring scholarly work outside these customary outputs (NISO, 2014). These non-standard artefacts can include 
software, scientific data sets, video, and images (Galligan \& Dyas-Correia, 2013; Kousha \& Thelwall, 2015).

Impactful research needs to be done and be seen to be done. The rationale of this study is to investigate traditional citation metrics and altmetric measures in the field of CI research. The landscape of Community Informatics research has similarities and overlaps with Development Informatics (Stillman \& Linger, 2009); therefore the literature on bibliometric analysis and authoring patterns in DI is considered relevant to CI research. Based on a recent bibliometric study of the ICT4D field, Naude (2016b) identified an absence of bibliometric studies in this academic area. Alperin (2015) pinpoints the need for studies that investigate the altmetrics of research, journals, and articles published and read in a developing country towards an emerging region's perspective (Alperin et al., 2014). The lack of altmetrics research and data from developing nations make it difficult to determine the impact and value of altmetrics in the developing context. In this paper we present a bibliometric and altmetric analysis of the Journal of Community Informatics (JOCI). JOCI is an international peer-reviewed, online open access journal, established in 2004 to create a space for CI in the academic environment (Less, 2008).

The Ulrich's Global Serials Directory indicates that Journal of Community Informatics (ISSN 1712-4441) is a quarterly publication, published by the Centre for Community Informatics Research in Canada. Ulrich's also indicates poor indexing coverage of JOCI in subject-specific bibliographic and abstract databases, which limits the accessibility, discoverability, and visibility of articles and authors that publish in this journal.

JOCI was selected for analysis due to the emphasis on community and development informatics research and the relevance thereof for CI researchers' profiles. This study which analyses the publication data from 2004 to 2015, complements our previous study (Van Biljon, Naudé, \& Lotriet, 2016), which focused on the article production, authorship, and collaboration patterns in JOCI and the correlation between the following article-level indicators: usage metrics (article views), altmetrics (Mendeley readership), and traditional citation metrics (Google Scholar). Furthermore, the indicators were used to identify, compare, and rank the most impactful JOCI articles.

\section{Literature review}

\section{Bibliometric and altmetric analyses}

A single journal bibliometric study is a quantitative tool to profile and characterise the scholarly literature published in a subject discipline by systematically analysing the articles published in an academic journal in a selected time period. A bibliometric assessment of an individual journal will reveal elements such as publication trends, article productivity and growth, authorship patterns, collaboration style, as well as the influential papers and authors in a research field. A review article by Wan, Anyi, Zainab, Anuar and Anyi (2009) summarises 82 single journal bibliometric studies published between 1998 and 2008 from various disciplines. A number of single journal studies published in all disciplines in the literature show the value of bibliometric analysis 
(Bakri \& Willett, 2008, 2009; Dwivedi, Lal, Mustafee, \& Williams, 2009; Dwivedi, Kiang, Lal, \& Williams, 2008; Dwivedi \& Kuljis, 2008; Jeyasekar \& Saravanan, 2014; Minas, Wright, Zhao, \& Kakuma, 2014; Rao, Sharma, Devi, \& Muralidhar, 2014; Sanni \& Zainab, 2010; Swain, Swain, \& Rautaray, 2013; Swain, 2013, 2014; Swain \& Panda, 2012).

Citations are an accepted standard of measuring research impact (Von Solms \& Von Solms, 2016). Alternative metrics, such as downloads and Mendeley readership hold the promise of developing indicators for measuring scholarly work outside the limitations of traditional citation metrics (NISO, 2014). Mendeley is a reference manager which was launched in 2007 and acquired by Elsevier in April 2013. Mendeley readership can be defined as the number of Mendeley users who have added a paper to their personal Mendeley library. Alternative metrics are particularly useful in interdisciplinary research which challenges the traditional delineation of subject areas. However, to propose altmetrics as a credible measure of research impact it is necessary to consider the correlation between citations and altmetric measures. Table 1 summarises a literature review of the correlation between citations and article views or downloads by considering the comparison detail, the results and the findings.

Table 1: Comparison of studies on the correlation between citations and downloads

\begin{tabular}{|l|l|l|c|}
\hline \multicolumn{1}{|c|}{ Comparison detail } & \multicolumn{1}{|c|}{ Results } & \multicolumn{1}{|c|}{ Findings } & Citation \\
\hline $\begin{array}{l}\text { Google Scholar citations and } \\
\text { Social Science Citation Index } \\
\text { (SSCI) relationship to the 200 } \\
\text { top downloaded papers in the } \\
\text { RePEc Digital Library in 2006. }\end{array}$ & $\begin{array}{l}\text { A single downloaded } \\
\text { paper on average } \\
\text { receives twice as many } \\
\text { citations from Google } \\
\text { Scholar as from SSCI. }\end{array}$ & $\begin{array}{l}\text { Downloads appear to have a } \\
\text { moderate relationship with } \\
\text { citations. }\end{array}$ & $\begin{array}{c}\text { Chu \& Krichel } \\
\text { (2007) }\end{array}$ \\
\hline $\begin{array}{l}\text { Google Scholar citations and } \\
\text { downloads by examining the } \\
\text { top 50 most downloaded } \\
\text { papers between January 2000 } \\
\text { and December 2002, published } \\
\text { in the journal Intelligent } \\
\begin{array}{l}\text { Systems in Accounting, } \\
\text { Finance and Management: An } \\
\text { International Journal. }\end{array}\end{array}$ & $\begin{array}{l}\text { The number of } \\
\text { downloads and citations } \\
\text { were highly correlated. }\end{array}$ & $\begin{array}{l}\text { Downloads are a leading } \\
\text { indicator of citations even } \\
\text { years into the future. }\end{array}$ & O'Leary (2009) \\
\hline $\begin{array}{l}\text { Randomised controlled trial of } \\
\text { open access publishing } \\
\text { involving 3245 articles in 36 } \\
\text { journals in the sciences, social } \\
\text { sciences and humanities. }\end{array}$ & $\begin{array}{l}\text { Open access articles } \\
\text { received significantly } \\
\text { more downloads. }\end{array}$ & $\begin{array}{l}\text { Downloads had no effect on } \\
\text { article citations within the } \\
\text { first three years after } \\
\text { publication }\end{array}$ & Davis (2011) \\
\hline $\begin{array}{l}\text { Evaluated the Scopus citations } \\
\text { and download figures for the } \\
\text { 50 most viewed articles from } \\
\text { five BioMed Central open } \\
\text { access oncology journals. }\end{array}$ & $\begin{array}{l}\text { Correlation between } \\
\text { downloads and citations } \\
\text { was limited. }\end{array}$ & Limited correlation & \\
\hline
\end{tabular}




\begin{tabular}{|l|l|l|l|}
\hline $\begin{array}{l}\text { Differences between citation } \\
\text { and downloads from 2002 to } \\
\text { 2011 for four ScienceDirect } \\
\text { categories that included arts } \\
\text { and humanities, computer } \\
\text { science, economics, } \\
\text { econometrics \& finance, and } \\
\text { oncology. }\end{array}$ & $\begin{array}{l}\text { Results indicated that } \\
50-140 \text { downloads } \\
\text { corresponded to one } \\
\text { citation. }\end{array}$ & $\begin{array}{l}\text { The disciplines with the } \\
\text { highest download rates were } \\
\text { different from those with the } \\
\text { highest citation rates. }\end{array}$ & $\begin{array}{l}\text { Gorraiz, } \\
\text { Gumpenberge, \& } \\
\text { Schlögl (2014) }\end{array}$ \\
\hline $\begin{array}{l}\text { A cross sectional study of the } \\
\text { papers published in the } \\
\text { International Review of } \\
\text { Research in open and distance } \\
\text { learning journal, for the period } \\
\text { 2008 to October 2013. }\end{array}$ & $\begin{array}{l}\text { A significant and } \\
\text { positive relationship } \\
\text { between the total } \\
\text { number of Google } \\
\text { Scholar citations and } \\
\text { the number of views or } \\
\text { downloads received by } \\
\text { the articles. }\end{array}$ & $\begin{array}{l}\text { Significant and positive } \\
\text { relationship between the total } \\
\text { number of Google Scholar } \\
\text { citations and the number of } \\
\text { downloads. }\end{array}$ & Anderson, 2015) \\
Aartinez \& \\
\hline
\end{tabular}

The contrasting findings reveal that there is no clear and decisive answer to the question whether views or downloads can predict citations yet. However, there is some logic inherent to the fact that a paper needs to be downloaded in order to be cited and therefore downloads are considered an important usage metric. It will be used in this study when investigating the metrics that support the sustainability of a CI researcher's profile. Given the increasing impact of social media, it is necessary to consider alternative metrics.

This paper will consider Mendeley readership as the alternative metrics indicator with the most significant correlation to traditional citations. Table 2 summarises studies that compare traditional citation counts with Mendeley readership.

Table 2: Comparison of citations with Mendeley readership

\begin{tabular}{|l|l|l|l|}
\hline \multicolumn{1}{|c|}{ Comparison detail } & \multicolumn{1}{|c|}{ Results } & \multicolumn{1}{|c|}{ Findings } & Citation \\
\hline $\begin{array}{l}\text { A sample of 1613 papers } \\
\text { published in 2007 in Nature } \\
\text { and Science. }\end{array}$ & $\begin{array}{l}\text { The correlations between the } \\
\text { Mendeley readership counts, } \\
\text { Google Scholar and Web of } \\
\text { Science citations showed a } \\
\text { nearly perfect relationship. }\end{array}$ & $\begin{array}{l}\text { Statistically significant } \\
\text { correlations between the } \\
\text { Mendeley readership } \\
\text { counts and traditional } \\
\text { citation sources. }\end{array}$ & $\begin{array}{l}\text { Li, Thelwall, \& } \\
\text { Giustini (2012) }\end{array}$ \\
\hline $\begin{array}{l}\text { 1459 articles published in the } \\
\text { Journal of the American } \\
\text { Society for Information Science } \\
\text { and Technology, between 2001 } \\
\text { and 2010. }\end{array}$ & $\begin{array}{l}\text { Citation counts from Web of } \\
\text { Science, Scopus and Google } \\
\text { Scholar were compared to } \\
\text { Mendeley readership counts } \\
\text { during April 2012. }\end{array}$ & $\begin{array}{l}\text { Significant correlations } \\
\text { between Mendeley } \\
\text { readership counts and } \\
\text { citation counts. }\end{array}$ & Bar-Ilan (2012) \\
\hline $\begin{array}{l}\text { Random sample of 20 000 } \\
\text { publications, from all } \\
\text { disciplines, published between } \\
\text { 2005 and 2011 and covered by } \\
\text { the Web of Science compared } \\
\begin{array}{l}\text { Mendeley, Twitter, Wikipedia } \\
\text { and Delicious. }\end{array}\end{array}$ & $\begin{array}{l}\text { Mendeley had the highest } \\
\text { coverage for altmetric data. }\end{array}$ & $\begin{array}{l}\text { Mendeley is currently the } \\
\text { leading and most } \\
\text { important altmetrics } \\
\text { indicator across all } \\
\text { research disciplines. }\end{array}$ & $\begin{array}{l}\text { Zahedi, Costas, \& } \\
\text { Wouters (2014) }\end{array}$ \\
\hline $\begin{array}{l}\text { Use and coverage of Mendeley } \\
\text { among 71 bibliometricians. }\end{array}$ & $\begin{array}{l}\text { Moderate correlation between } \\
\text { Scopus citation counts and } \\
\text { Mendeley readership. }\end{array}$ & $\begin{array}{l}\text { Mendeley was the most } \\
\text { popular citation manager } \\
\text { among the } \\
\text { bibliometricians } \\
\text { surveyed. }\end{array}$ & $\begin{array}{l}\text { Haustein et al. } \\
\text { (2014) }\end{array}$ \\
\hline
\end{tabular}




\begin{tabular}{|l|l|l|l|}
\hline $\begin{array}{l}\text { Scopus articles published } \\
\text { between 2004 and 2014 in five } \\
\text { broad fields and 50 subfields in } \\
\text { agriculture, business, decision } \\
\text { science, pharmacy and social } \\
\text { sciences. }\end{array}$ & $\begin{array}{l}\text { Positive correlations between } \\
\text { aendeley readership counts } \\
\text { and Scopus citation counts for }\end{array}$ & $\begin{array}{l}\text { Correlations between } \\
\text { citation counts and } \\
\text { aendeley reader counts } \\
\text { for journal articles tend to } \\
\text { increase over five years } \\
\text { and then stabilise. }\end{array}$ & $\begin{array}{l}\text { Thelwall \& Sud } \\
(2015)\end{array}$ \\
\hline
\end{tabular}

The findings as presented in the third column of table 2 substantiate the importance of Mendeley as an altmetric indicator for which evidence of correlations with citation counts have been found. This supports the selection of Mendeley readership as an altmetrics indicator during the research design of this paper, to investigate the metrics that support the impact of a CI researcher's profile.

\section{Previous studies on the Journal of Community Informatics}

A survey of the literature revealed only one citation study of JOCI and one bibliometric analysis. Less (2008) conducted a citation analysis on 29 articles published in JOCI for the publication years 2004 to 2005. The list of references sections of the 29 articles was analysed. A total of 541 citations were evaluated. The most influential authors, articles and journals were analysed. Dr Michael Gurstein, Executive Director of the Centre for Community Informatics Research, Development and Training (CCIRDT) and Chief Editor of JOCI, was the most influential author, with 93\% of articles examined in this study that cited Dr Gurstein. Dr Barry Wellman from University of Toronto was also influential, with $76 \%$ articles citing him. Authors with academic affiliations were cited more than authors affiliated with government, corporate or non-profit institutions. The highest number of academics cited was affiliated with the University of Toronto (Canada) and Queensland University of Technology (Australia). The highest number of author citations for an academic institution came from the University of Toronto and for a non-academic institution was the CCIRDT. Results indicated that the largest proportion of authors was affiliated with the academic disciplines of sociology $(24.40 \%)$, communication $(11.20 \%)$, and library and information science $(11 \%)$. The results also showed that most of the publications cited in JOCI were published within the last four or five years.

The bibliometric analysis was performed on the articles published in JOCI for the publication years 2004 to 2015 (Van Biljon et al., 2016). That study presented the article production, authorship and collaboration patterns in JOCI as well as the results of an initial investigation into the correlation between the following article-level indicators: traditional citation metrics (Google Scholar), usage metrics (article views or downloads), and altmetrics (Mendeley readership).

In summary it can be said that the two previous studies that investigated JOCI do not provide the annual distribution or authorship distribution of the article views, Mendeley readership, and Google Scholar citations. Previous analysis on the most influential papers have only been for the publication years 2004 to 2005 whereas this study extends the period to 2015 . 


\section{Methodology}

\section{The Journal of Community Informatics}

The focus and scope of JOCI is described on the JOCI website (http://www.cijournal.net) as follows:

"Community Informatics (CI) is the study and the practice of enabling communities with Information and Communications Technologies (ICTs). CI seeks to work with communities towards the effective use of ICTs to improve their processes, achieve their objectives, overcome the "digital divides" that exist both within and between communities, and empower communities and citizens in the range of areas of ICT application including for health, cultural production, civic management, and e-governance, among others. CI is concerned with how ICT can be useful to the range of traditionally excluded populations and communities, and how it can support local economic development, social justice and political empowerment using the Internet. CI is a point of convergence concerning the use of ICTs for diverse stakeholders, including community activists, non-profit groups, policymakers, users/citizens, and the range of academics working across (and integrating) disciplines as diverse as Information Studies, Management, Computer Science, Social Work, Planning and Development Studies. Emerging issues within the CI field include: community access to the internet, community information, online civic participation and community service delivery, community and local economic development, training networks, telework, social cohesion, learning, e-health and e-governance."

The target audience of JOCI is academics, CI practitioners and national and multilateral policy makers. The readership focus of JOCI is global, including the developing world. No subscription or registration is required to access the full-text articles of the journal. The articles are published in HTML and PDF format.

The citation analysis tools available are the academic citation enhanced databases Web of Science (Thomson Reuters) and Scopus (Elsevier), and the free academic search engine and internet resource, Google Scholar. The JOCI is not indexed in Web of Science or Scopus, making the citation enhanced databases unfeasible for a citation study of JOCI. The absence of electronic bibliometric tools and citation data complicates the assessment of scholarly productivity as well as the identification and comparison of popular papers and distinguished authors in the CI discipline. JOCI is discoverable, accessible and visible via the free non-commercial resources Google Scholar and Mendeley Papers crowdsourced research catalogue. 


\section{Data collection and analysis}

A single journal analysis was the focus of this research study. 260 articles published in the 11 volumes of the open access peer-reviewed Journal of Community Informatics (JOCI) for the period 2004 to 2015 were analysed. Only research articles were included; editorial introductions, reports, points of view, case studies, reviews, commentaries, notes, and cases from the field were excluded. All articles were in English, except for five articles in Spanish and Portuguese that were published in 2007 (volume 3, issue 3). The data for this study was collected during July 2016.

The JOCI bibliographic details for the publication years 2004 to 2015 were imported from Google Scholar into Mendeley. The 260 bibliographic records were exported from Mendeley to Refworks and subsequently to an MS Excel spreadsheet for analysis. Figure 1 shows the data collection process.

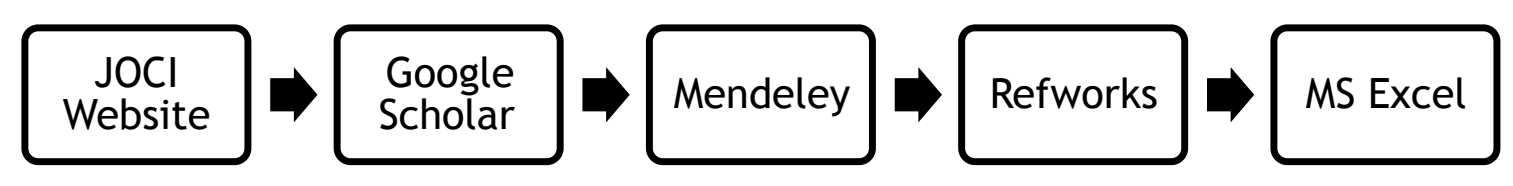

Figure 1: Data collection process

The bibliographic data retrieved were checked for completeness. The JOCI contents pages on the online e-journal homepage, published on the free, publicly available, open access journal archive on the JOCI website (http://ci-journal.net), were compared to the bibliographic data downloaded from Google Scholar. Missing bibliographic items were imported from the JOCI website into the Mendeley account. The following descriptive bibliographic details for each article were collected:

- Article title

- Author names

- Source information: journal title, volume and issue

- Year of publication

The number of authors, Google Scholar citations, Mendeley readership and article views were recorded manually and added to the spreadsheet for each article. This study used free web-based public data sources to record the following article-level data:

- Usage data: JOCI article views (i.e. number of times an article was viewed on the JOCI website)

- Mendeley crowdsourced readership scores (i.e. the number of Mendeley users that added a JOCI paper to their personal Mendeley library) (Gunn, 2013).

- Google Scholar citation counts (i.e. number of citations per JOCI article). 
The journal usage statistics (article views) that are freely available on the JOCI website (http://ci-journal.net/reports) were recorded on the spreadsheet. All articles had views, except for one 2015 article published in volume 11 number 1.

Mendeley Readership scores are freely available in the Mendeley Papers Research Catalogue (http://www.mendeley.com). To access and search the Mendeley Papers Research Catalogue, users need to register for a free online Mendeley account. A Mendeley Public group was created "Journal of Community Informatics 2004-2015" (https:/www.mendeley.com/groups/9033091/journal-of-communityinformatics-2004-2015)

The JOCI bibliographic data for the period 2004 to 2015 was shared from a Mendeley account to the public Mendeley group. This enabled the researchers to view and record the Mendeley readership data for each article. Mendeley readership statistics were available for all 260 items. The Mendeley readership data was recorded manually on 14 July 2016 from the Mendeley Group for each article and entered into the Excel spreadsheet.

Each article was searched individually in Google Scholar to find the number of citations it received. The Google Scholar citation data for each item was recorded on the spreadsheet.

The final article count of 260 items of bibliographic data served as the study population for this study. The investigation is limited to one open access journal, which limits the generalisability of the results.

\section{Results and discussion}

\section{Article Productivity}

Table 3 depicts the article productivity for JOCI over a 12-year period (2004 to 2015). A total of 260 journal articles were published in 11 volumes and 33 issues (excluding the editorial introductions, reports, points of view, case studies, reviews, commentaries, notes, and cases from the field). Table 3 indicates that the highest number of articles was published in 2013, totalling 40 articles and the lowest publication rate was in 2004 with 9 articles, when the journal was launched. The mean number of articles published per year was 21.75 .

Table 3: JOCI annual number of volumes, issues and articles

\begin{tabular}{|c|c|c|c|c|}
\hline Year & $\begin{array}{c}\text { Volume } \\
\text { number }\end{array}$ & $\begin{array}{c}\text { Number } \\
\text { of issues }\end{array}$ & $\begin{array}{c}\text { Number of } \\
\text { articles }\end{array}$ & $\%$ \\
\hline 2004 & 1 & 1 & 9 & 3.45 \\
\hline 2005 & 1 & 2 & 14 & 5.36 \\
\hline 2006 & 2 & 3 & 28 & 11.11 \\
\hline 2007 & 3 & 4 & 22 & 8.43 \\
\hline
\end{tabular}




\begin{tabular}{|l|l|l|l|l|}
\hline 2008 & 4 & 3 & 13 & 4.98 \\
\hline 2009 & 5 & 3 & 20 & 7.66 \\
\hline 2010 & 6 & 2 & 18 & 6.90 \\
\hline 2011 & 7 & 2 & 15 & 5.75 \\
\hline 2012 & 8 & 3 & 25 & 9.58 \\
\hline 2013 & 9 & 4 & 40 & 15.32 \\
\hline 2014 & 10 & 3 & 32 & 12.26 \\
\hline 2015 & 11 & 3 & 24 & 9.20 \\
\hline Total & & 33 & 260 & 100 \\
\hline
\end{tabular}

\section{Authorship}

The results for the number of authors per article are depicted in figure 2. Overall 571 authors were involved in publishing the 260 articles in JOCI between 2004 and 2015. Of those articles, $37 \%$ had only one author; this was followed by the percentage with two authors (32\%) and that with three authors (19\%), and so forth. Those with more than six authors (those with 7,8 and even 11) were all grouped under seven, which add up to $1 \%$ of the papers published. From observation it seems like the number of authors could be inversely related to the number of papers published per number of authors. This means that $37 \%$ of the 260 articles were single-authored while $165(63 \%)$ were multi-authored articles. This shows that JOCI has a collaborative authorship pattern, with collaboration varying between two and eleven authors. A study by Naude (2016b) of the Electronic Journal of Information Systems in Developing Countries (EJISDC) research articles, showed similar results, with 34\% single-authored compared to $66 \%$ multi-authored articles.

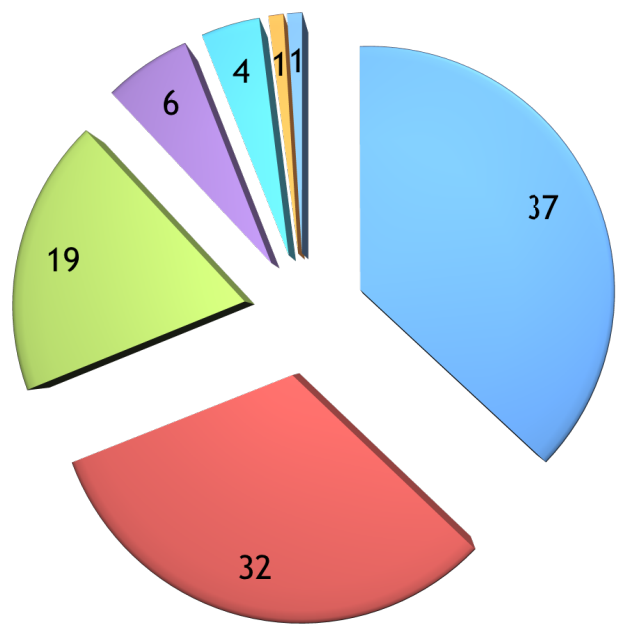

One author

Two authors

Three authors

Four authors

Five authors

Six authors

Seven authors

Figure 2: Percentage of number of authors per article 


\section{Collaboration}

Subramanyam defines the degree of collaboration in a discipline as "the ratio of the number of collaborative research papers to the total number of research papers published in the discipline during a certain period of time" (Subramanyam, 1983, p. 37). Subramanyam's formula: $\mathrm{C}=\mathrm{Nm} /(\mathrm{Ns}+\mathrm{Nm})$, where $\mathrm{C}=$ the degree of collaboration, $\mathrm{Nm}=$ the number of multi-authored papers, and $\mathrm{Ns}=$ number of single-authored papers. This formula was used to calculate the degree of collaboration, as shown in table 4 . The degree of collaboration per year varied between a minimum of 0.48 in 2012 and a maximum of 0.80 in 2011. The average degree of collaboration in JOCI was 0.63. Therefore, more than $60 \%$ of papers involved collaboration between two or more authors and the collaboration trend shows no signs of diminishing. The results can be compared to the EJISDC study (Naude, 2016a) that showed a similar collaborative publication culture. The overall degree of collaboration in the EJISDC was 0.66.

Table 4: Degree of collaboration by year

\begin{tabular}{|l|c|c|c|c|}
\hline Year & $\begin{array}{c}\text { Single } \\
\text { authorship }\end{array}$ & $\begin{array}{c}\text { Multi } \\
\text { authorship }\end{array}$ & $\begin{array}{c}\text { Degree of } \\
\text { collaboration }\end{array}$ & $\begin{array}{c}\text { Total } \\
\text { articles }\end{array}$ \\
\hline $\mathbf{2 0 0 4}$ & 3 & 6 & 0.67 & 9 \\
\hline $\mathbf{2 0 0 5}$ & 5 & 9 & 0.64 & 14 \\
\hline $\mathbf{2 0 0 6}$ & 8 & 20 & 0.71 & 28 \\
\hline $\mathbf{2 0 0 7}$ & 8 & 14 & 0.64 & 22 \\
\hline $\mathbf{2 0 0 8}$ & 6 & 7 & 0.54 & 20 \\
\hline $\mathbf{2 0 0 9}$ & 9 & 11 & 0.55 & 18 \\
\hline $\mathbf{2 0 1 0}$ & 8 & 10 & 0.56 & 15 \\
\hline $\mathbf{2 0 1 1}$ & 3 & 12 & 0.80 & 25 \\
\hline $\mathbf{2 0 1 2}$ & 13 & 12 & 0.48 & 40 \\
\hline $\mathbf{2 0 1 3}$ & 12 & 28 & 0.70 & 32 \\
\hline $\mathbf{2 0 1 4}$ & 11 & 21 & 0.66 & 24 \\
\hline $\mathbf{2 0 1 5}$ & 9 & 15 & 0.63 & $\mathbf{2 6 0}$ \\
\hline Total & $\mathbf{9 5}$ & $\mathbf{1 6 5}$ & $\mathbf{0 . 6 3}$ & \\
\hline
\end{tabular}

\section{Article-level metrics}

The article-level measures captured were article views for the JOCI articles, the Mendeley readership, and the Google Scholar citations.

Annual distribution of Article views, Mendeley readership, and Google Scholar citations

Table 5 shows the annual distribution of article views, Mendeley readership and Google Scholar citations over a 12 -year period. The 260 articles in JOCI received a total of 1,668,042 article views, 3,583 Mendeley readers and 2,781 Google Scholar citations, as measured in July 2016. The average (arithmetic mean) number of article views was 
139,003, the average Mendeley readership was 298 and Google Scholar citations was 232.

Table 5: JOCI annual distribution of Article Views, Mendeley Readership, and Google Scholar citations

\begin{tabular}{|l|c|c|c|c|c|c|c|c|c|}
\hline Year & $\begin{array}{c}\text { Vol } \\
\text { Nr }\end{array}$ & $\begin{array}{c}\text { Nr of } \\
\text { articles }\end{array}$ & $\mathbf{\%}$ & $\begin{array}{c}\text { Article } \\
\text { Views }\end{array}$ & $\mathbf{\%}$ & $\begin{array}{c}\text { Mendeley } \\
\text { Readership }\end{array}$ & \% & $\begin{array}{c}\text { GS } \\
\text { citations }\end{array}$ & $\%$ \\
\hline $\mathbf{2 0 0 4}$ & 1 & 9 & 3.45 & 41519 & 2.49 & 102 & 2.85 & 284 & 10.21 \\
\hline $\mathbf{2 0 0 5}$ & 1 & 14 & 5.36 & 63215 & 3.79 & 324 & 9.04 & 615 & 22.11 \\
\hline $\mathbf{2 0 0 6}$ & 2 & 28 & 11.11 & 142140 & 8.52 & 455 & 12.7 & 512 & 18.41 \\
\hline $\mathbf{2 0 0 7}$ & 3 & 22 & 8.43 & 211030 & 12.65 & 272 & 7.59 & 209 & 7.52 \\
\hline $\mathbf{2 0 0 8}$ & 4 & 13 & 4.98 & 265574 & 15.92 & 180 & 5.02 & 228 & 8.2 \\
\hline $\mathbf{2 0 0 9}$ & 5 & 20 & 7.66 & 172884 & 10.36 & 205 & 5.72 & 111 & 3.99 \\
\hline $\mathbf{2 0 1 0}$ & 6 & 18 & 6.90 & 108975 & 6.53 & 212 & 5.92 & 121 & 4.35 \\
\hline $\mathbf{2 0 1 1}$ & 7 & 15 & 5.75 & 87896 & 5.27 & 222 & 6.2 & 102 & 3.67 \\
\hline $\mathbf{2 0 1 2}$ & 8 & 25 & 9.58 & 288794 & 17.31 & 441 & 12.31 & 335 & 12.05 \\
\hline $\mathbf{2 0 1 3}$ & 9 & 40 & 15.32 & 158978 & 9.53 & 470 & 13.12 & 144 & 5.18 \\
\hline $\mathbf{2 0 1 4}$ & 10 & 32 & 12.26 & 100838 & 6.05 & 391 & 10.91 & 113 & 4.06 \\
\hline $\mathbf{2 0 1 5}$ & 11 & 24 & 9.20 & 26199 & 1.58 & 309 & 8.62 & 7 & 0.25 \\
\hline Total & & $\mathbf{2 6 0}$ & $\mathbf{1 0 0}$ & $\mathbf{1 6 6 8 0 4 2}$ & $\mathbf{1 0 0}$ & $\mathbf{3 5 8 3}$ & $\mathbf{1 0 0}$ & $\mathbf{2 7 8 1}$ & $\mathbf{1 0 0}$ \\
\hline
\end{tabular}

Authorship distribution of Article Views, Mendeley Readership and Google Scholar citations

Table 6 shows the authorship distribution of article views, Mendeley readership and Google Scholar citations.

Table 6: JOCI authorship distribution of Article Views, Mendeley Readership and Google Scholar citations

\begin{tabular}{|l|c|c|c|c|c|c|c|c|}
\hline $\begin{array}{l}\text { Number } \\
\text { of authors }\end{array}$ & $\begin{array}{c}\text { Number of } \\
\text { articles }\end{array}$ & $\%$ & $\begin{array}{c}\text { Article } \\
\text { views }\end{array}$ & $\%$ & $\begin{array}{c}\text { Mendeley } \\
\text { readershi } \\
\mathbf{p}\end{array}$ & $\mathbf{\%}$ & GS citations & $\%$ \\
\hline 1 author & 95 & 36.54 & 602328 & 36.11 & 1293 & 36.09 & 1030 & 37.04 \\
\hline 2 authors & 83 & 31.92 & 678997 & 40.71 & 1228 & 34.27 & 1154 & 41.5 \\
\hline 3 authors & 50 & 19.23 & 255471 & 15.32 & 647 & 18.07 & 361 & 12.97 \\
\hline 4 authors & 15 & 5.78 & 67598 & 4.05 & 223 & 6.22 & 129 & 4.64 \\
\hline 5 authors & 11 & 4.24 & 39662 & 2.38 & 114 & 3.18 & 59 & 2.12 \\
\hline 6 authors & 3 & 1.15 & 13591 & 0.81 & 38 & 1.06 & 16 & 0.58 \\
\hline 7 authors & 1 & 0.38 & 4521 & 0.27 & 15 & 0.42 & 31 & 1.11 \\
\hline 9 authors & 1 & 0.38 & 3664 & 0.22 & 13 & 0.36 & 0 & 0 \\
\hline 11 authors & 1 & 0.38 & 2210 & 0.13 & 12 & 0.33 & 1 & 0.04 \\
\hline
\end{tabular}




\begin{tabular}{|l|l|l|l|l|l|l|l|l|}
\hline Total & 260 & 100 & 1668042 & 100 & 3583 & 100 & 2781 & 100 \\
\hline
\end{tabular}

Statistical comparison of article views, Mendeley readership and Google Scholar citations

A Spearman correlation analysis was conducted to examine whether there is a relationship between article views, Mendeley readership, and Google Scholar citations. Table 7 shows the relationship (Spearman correlation) between article views, Mendeley readership, and Google Scholar citations:

- A statistically significant and positive linear relationship $(\mathrm{p}<0.0001)$ of medium strength $(\mathrm{r}=0.51 ; \mathrm{N}=260)$ between article views and Google Scholar citations.

- A statistically significant and positive linear relationship ( $\mathrm{p}<0.0001)$ of medium strength ( $r=0.50 ; \mathrm{N}=260$ ) between Google Scholar citations and Mendeley.

- A statistically significant and positive linear relationship ( $\mathrm{p}<0.0001)$ of medium to weak strength $(\mathrm{r}=0.25 ; \mathrm{N}=260)$ between Mendeley readership and article views.

For this journal, the results in table 7 seem to indicate that the highest correlations (Spearman) were between Google Scholar citations and article views, a slightly lower correlation between Google Scholar citations and Mendeley readership, and the lowest correlation was between Mendeley readership and article views.

Table 7: Spearman correlations between Article views, Mendeley readership and Google Scholar citations

\begin{tabular}{|l|l|c|c|}
\hline Variable & Variable & Correlation & Signif Prob \\
\hline Article views & Google Scholar & 0.5116 & $<.0001^{*}$ \\
\hline Mendeley & Google Scholar & 0.5001 & $<.0001^{*}$ \\
\hline Article views & Mendeley & 0.2558 & $<.0001 *$ \\
\hline
\end{tabular}

This results can be compared to an article-level metric study of the EJISDC (Naude, 2017) that showed that the highest correlations (Spearman) were between Google Scholar citations and article downloads or views, a slightly lower correlation between Google Scholar citations and Mendeley readership, and the lowest correlation was between downloads and Mendeley readership.

\section{JOCI influential articles}

In this study, the impact of JOCI articles was assessed by counting how many times it was viewed, read, or cited. Three article-level indicators were used to sort JOCI articles, based on usage indicators (views in table 8, in the appendix), readership indicators (Mendeley in table 9, in the appendix), and citation indicators (Google Scholar in table 10, in the appendix). The influential articles are listed in tables 8, 9 and 10 and show how the ranking and impact change, depending on the indicator used. 
An influential article, for the purpose of this study, is defined as an article that is among the leading 20 articles, ranked by article views, Mendeley readership, or Google Scholar citations, published in the JOCI during the period 2004 to 2015.

\section{Article views}

Table 8 (in the appendix) lists the 20 JOCI articles that were viewed the most. It also indicates if the article was among the top 20 influential articles as ranked by Google Scholar citations and Mendeley readership, as indicated by the symbol $\checkmark$. Of the 20 heavily viewed articles in table 8 , five of the articles were among the top articles by Google Scholar citations and five were also among the top articles ranked by Mendeley readership scores.

The most viewed article (143,425 views) was an article by Kate Williams (University of Illinois) and Joan C. Durrance (University of Michigan), published in 2008 with the title "Social networks and Social Capital rethinking theory in community informatics". This article was listed among the top 20 articles by Mendeley readership and by Google Scholar citations.

\section{Mendeley readership}

Table 9 (in the appendix) lists the top 20 articles with the highest Mendeley readership scores. It also shows if the article was among the top 20 influential articles as ranked by Google Scholar citations and article views, indicated by the symbol $\checkmark$. Of the 20 eminent articles listed in table 9, ranked by Mendeley readership scores, twelve were among the top articles by Google Scholar citations and five were also among the top articles ranked by article views.

The article with the most Mendeley readers (85 Mendeley readers) was a solo-authored article by Harekrishna Misra (Institute of Rural Management Anand, India) published in 2015 with the title "Information kiosk based Indian E-Governance service delivery: Value chain based measurement modelling" This article was not listed among the top 20 articles ranked by Google Scholar citations or by article views.

\section{Google Scholar citations}

Table 10 (in the appendix) lists the articles with the most Google Scholar citations. It also shows if the articles were among the top 20 influential articles as ranked by Mendeley readership and article views, indicated by the symbol $\checkmark$. Of the 20 eminent articles in table 10 ranked by Google Scholar citations, 12 were among the top articles by Mendeley readership and five were also among the top articles ranked by article views.

The most cited article (134 Google Scholar citations) was by Ke Pigg and L.D. Crank (University of Missouri), published in 2004 entitled "Building community social capital: The potential and promise of information and communications technologies". 
This article was not listed among the top 20 viewed articles, but as a top 20 article by Mendeley readership.

\section{Top articles by Article views, Mendeley Readership, and Google Scholar Citations}

Table 11 lists the four top JOCI articles overall in the publication period 2004 to 2015. This represents the overlap in the top 20 articles (tables 8, 9, and Tale 10) as ranked by article view statistics, Mendeley readership scores, and Google Scholar citations. Only the four articles listed in table 11 are among the top 20 articles that were the most viewed, had a high Mendeley readership, and were highly cited in Google Scholar. All four articles were authored in developed countries.

Table 11: Top articles by Article views, Mendeley readership and Google Scholar citations

\begin{tabular}{|c|c|c|c|c|c|c|c|c|}
\hline Rank & Article Title & Year & Authors & Affiliation & Country & $\begin{array}{c}\text { Article } \\
\text { views }\end{array}$ & Mendeley & GS \\
\hline 1 & $\begin{array}{l}\text { Social networks and } \\
\text { Social Capital } \\
\text { rethinking theory in } \\
\text { community } \\
\text { informatics }\end{array}$ & 2008 & $\begin{array}{l}\text { K } \\
\text { Williams } \\
\text { J. C. } \\
\text { Durrance }\end{array}$ & $\begin{array}{l}\text { Univ. of } \\
\text { Illinois } \\
\text { Univ. of } \\
\text { Michigan }\end{array}$ & $\begin{array}{l}\text { USA } \\
\text { USA }\end{array}$ & 143425 & 32 & 105 \\
\hline 2 & $\begin{array}{l}\text { This is what modern } \\
\text { deregulation looks } \\
\text { like: co-optation and } \\
\text { contestation in the } \\
\text { shaping of the UK's } \\
\text { Open Government } \\
\text { Data Initiative }\end{array}$ & 2012 & J. Bates & $\begin{array}{l}\text { Manchester } \\
\text { Metropoli- } \\
\text { tan } \\
\text { University }\end{array}$ & UK & 22469 & 52 & 68 \\
\hline 3 & $\begin{array}{l}\text { Too old for } \\
\text { technology? How the } \\
\text { elderly of Lisbon use } \\
\text { and perceive ICT }\end{array}$ & 2012 & $\begin{array}{l}\text { B.B. } \\
\text { Neves } \\
\text { F. Amaro }\end{array}$ & $\begin{array}{l}\text { Univ. of } \\
\text { Lisbon } \\
\text { Univ. of } \\
\text { Lisbon }\end{array}$ & $\begin{array}{l}\text { Portugal } \\
\text { Portugal }\end{array}$ & 43828 & 66 & 50 \\
\hline 4 & $\begin{array}{l}\text { Towards participatory } \\
\text { action design } \\
\text { research: adapting } \\
\text { action research and } \\
\text { design science } \\
\text { research methods for } \\
\text { urban informatics }\end{array}$ & 2011 & $\begin{array}{l}\text { M. } \\
\text { Bilandzic } \\
\text { J. Venable }\end{array}$ & $\begin{array}{l}\text { Queensland } \\
\text { Univ. of } \\
\text { Technology } \\
\text { Curtin } \\
\text { University }\end{array}$ & $\begin{array}{l}\text { Australia } \\
\text { Australia }\end{array}$ & 18689 & 50 & 38 \\
\hline
\end{tabular}

\section{Conclusions}

There are unique challenges that confound the dissemination and impact measuring of CI research. This investigation revealed that JOCI has poor indexing coverage in commercial subject and bibliographic databases, complicating the accessibility, discoverability, and visibility of CI research. Focusing on JOCI as the main journal for the dissemination of $\mathrm{CI}$ research, it is concluded that traditional citation metrics have limited application in CI, due to the exclusion of JOCI in the sophisticated commercial electronic citation tools (Scopus and Web of Science) used to conduct bibliometric and citation assessments. This is intensified by the shortage of high-impact journals in the 
CI discipline, the open access status of the journal and the interdisciplinary nature of the field (Naude, 2016a).

The bibliometric analysis presented in this paper sheds light on the article production and authorship over a 12-year period and showed that $\mathrm{CI}$ is characterised by a collaborative or multi-authorship style. Furthermore, the coverage of JOCI in the new and emerging altmetric tools such as Mendeley, shows the increasing importance of new generation metrics, and highlights the significance of a multi-metric approach in measurement and evaluation of CI researchers or CI article impact. In response to the question, namely what research metrics should be considered in supporting CI research impact, it was thus concluded that altmetric indicators such as Mendeley readership or article views can be considered.

Given the complexities mentioned around CI as an interdisciplinary field and the lack of bibliometric data, the addition of altmetrics can make an important contribution to demonstrating research impact by drawing on a wider, richer and more representative data set. The limitation of this study is that it focuses only on JOCI, and therefore more research is needed to compare altmetrics measures from related journals.

The usage data, altmetric data, and citation metric data were used to identify and compare the influential articles published in JOCI. In the absence of electronic citation tools to find the most cited papers, this analysis is valuable in that it gives an indication of the JOCI articles with the highest usage, readership and citation over a 12-year period. The result is a portrait of the leading papers in the field of CI.

In a single journal bibliometric study on EJISDC research articles (2000-2013), Naude (2016b) found that single-authored papers are cited more often than multi-authored papers. This JOCI study did not examine the relationship between citations and the number of authors in this study, but further exploration would be useful. The strong positive correlation found between citations (in Google Scholar) and the altmetric indicator (of Mendeley readership) supports the use of Mendeley as an altmetrics measure and the potential of altmetrics as a measure of research impact in the CI field. Altmetrics can indicate the broader impact of CI research on societies and communities, that cannot be measured by traditional citation metrics (Bornmann, 2014). Altmetrics can reveal the engagement of wider non-academic audiences, for example public, communities, stakeholders, and CI practitioners with CI research. Given the complications with visibility of research from developing and emerging economies, this is an important insight towards ensuring equitable representation of research impact.

The purpose of this study was to investigate research metrics to support the impact of CI research. Based on the JOCI analysis (2004-2015) and the strong positive correlation between traditional citations measures and altmetrics we propose that altmetric should be considered in measuring CI research impact. However, more research is needed to consider other CI journals and to investigate the correlations between other alternative metric measures (like Twitter and Facebook) and traditional citation measures, before the findings can be generalised. 


\section{References}

Agarwal, A., Durairajanayagam, D., Tatagari, S., Esteves, S., Harlev, A., Henkel, R., Roychoudhury, S., et al. (2016). Bibliometrics: tracking research impact by selecting the appropriate metrics. Asian Journal of Andrology, 18(2), 296.

Alperin, J. P. (2015). Geographic variation in social media metrics: An analysis of Latin American journal articles. Aslib Journal of Information Management, 67(3), 1-19.

Alperin, J. P., Packer, A. L., Aguado-López, E., Spano, D., Archuby, G., Carrizo, V., García, D. A., et al. (2014). Open access indicators and scholarly communications in Latin America. Retrieved July 27, 2016, from http://eprints.rclis.org/25122

Bakri, A., \& Willett, P. (2008). The Malaysian Journal of Library and Information Science 2001-2006: A bibliometric study. Malaysian Journal of Library and Information Science, 13(1), 103-116.

Bakri, A., \& Willett, P. (2009). The Malaysian Journal of Computer Science: A bibliometric study. Malaysian Journal of Library and Information Science, 14(2), 39-49.

Bar-Ilan, J. (2012). JASIST 2001-2010. Bulletin of the American Society for Information Science and Technology, 38(6), 24-28.

Bornmann, L. (2014). Do altmetrics point to the broader impact of research? An overview of benefits and disadvantages of altmetrics. Journal of Informetrics, 8(4), 895-903.

Carroll, J. M., Shih, P. C., \& Kropczynski, J. (2015). Community informatics as innovation in sociotechnical infrastructures. Journal of community informatics, 11(2). Retrieved from $\mathrm{http} / / /$ linksource.ebsco.com/linking.aspx?

sid=ProQ\%253Aibssshell\&fmt=journal\&genre=article\&issn=17124441\&volume=11\&iss $\mathrm{ue}=2 \&$ date $=2015-01-01 \&$ spage $=\&$ title $=$ Journal + of + community + informatics \&atitle $=$ Com munity+informatics+as+innovation + in + sociotechnical + infrastruc

Chu, H., \& Krichel, T. (2007). Downloads vs. Citations: Relationships, Contributing Factors and Beyond, 1-11. Retrieved from http://openlib.org/home/krichel/papers/getafe.pdf

Davis, P. M. (2011). Open access, readership, citations: A randomized controlled trial of scientific journal publishing. FASEB Journal, 25(7), 2129-2134.

Dwivedi, Y. K., Kiang, M., Lal, B., \& Williams, M. D. (2008). Profiling research published in the Journal of Electronic Commerce Research. Journal of Electronic Commerce Research, $9(2), 77-91$.

Dwivedi, Y. K., \& Kuljis, J. (2008). Profile of IS research published in the European Journal of Information Systems. European Journal of Information Systems, 17(6), 678-693.

Dwivedi, Y. K., Lal, B., Mustafee, N., \& Williams, M. D. (2009). Profiling a decade of Information Systems Frontiers' research. Information Systems Frontiers, 11(1), 87-102.

Galligan, F., \& Dyas-Correia, S. (2013). Altmetrics: Rethinking the Way We Measure. Serials Review, 39(1), 56-61.

Gorraiz, J., Gumpenberger, C., \& Schlögl, C. (2014). Usage versus citation behaviours in four subject areas. Scientometrics, 101(2), 1077-1095.

Gunn, W. (2013). Social Signals Reflect Academic Impact: What it Means When a Scholar Adds a Paper to Mendeley. Information Standards Quarterly, 25(2), 33-39. Retrieved from http://www.niso.org/publications/isq/2013/v25no2/gunn/

Haustein, S., Peters, I., Bar-Ilan, J., Priem, J., Shema, H., \& Terliesner, J. (2014). Coverage and adoption of altmetrics sources in the bibliometric community. Scientometrics, 101(2), $1145-1163$. 
Jeyasekar, J., \& Saravanan, P. (2014). A Scientometric Portrait of the Journal Digital Investigation. Journal of Advances in Library and Information Science, 3(2), 155-162. Retrieved June 21, 2015, from http://jalis.in/pdf/3-2/John.pdf

Kousha, K., \& Thelwall, M. (2015). Web indicators for research evaluation. Part 3: books and non standard outputs. El Profesional de la Información, 24(6), 724. Retrieved from http:// www.elprofesionaldelainformacion.com/contenidos/2015/nov/04.pdf

Less, A. M. (2008). Community Informatics: A Bibiometric study of scholarly influence. University of North Carolina, School of Information and Library Science. Retrieved July 5, 2016, from http://ils.unc.edu/MSpapers/3386.pdf

Li, X., Thelwall, M., \& Giustini, D. (2012). Validating online reference managers for scholarly impact measurement. Scientometrics, 91(2), 461-471.

Lin, J., \& Fenner, M. (2013). Altmetrics in Evolution: Defining and Redefining the Ontology of Article Level Metrics. ISQ: Information Standards Quarterly, 25(2), 20-26.

Martinez, R. A., \& Anderson, T. (2015). Are the most highly cited articles the ones that are the most downloaded? A Bibliometric study of IRRODL. International Review of Research in Open and Distributed Learning Volume, 16(3), 18-40.

Minas, H., Wright, A., Zhao, M., \& Kakuma, R. (2014). International journal of mental health systems: A bibliometric study. International Journal of Mental Health Systems, 8(1).

Naude, F. (2016a). Electronic Journal of Information Systems in Developing Countries (2000-2013): A Bibliometric Study. Electronic Journal of Information Systems in Developing Countries, 72(3), 1-23.

Naude, F. (2016b). Country Trends and Scholarly Collaboration in the ICT4D Research Community 2000-2013: A Single Journal Study. Electronic Journal of Information Systems in Developing Countries, 72(4), 1-26.

Naude, F. (2017). Comparing Downloads, Mendeley Readership and Google Scholar Citations as indicators of article performance. Electronic Journal of Information Systems in Developing Countries, 78(4), 1-25.

Neylon, C., Willmers, M., \& King, T. (2013). Rethinking Impact: Applying Altmetrics to Southern African Research. Scholarly Communication in Africa Programme, 1-20. Retrieved from http://www.healthra.org/wp-content/uploads/2013/12/ SCAP_Neylon_Paper_1_Altmetrics_review.pdf

Nieder, C., Dalhaug, A., \& Aandahl, G. (2013). Correlation between article download and citation figures for highly accessed articles from five open access oncology journals. SpringerPlus, 2(261), 1-5.

NISO. (2014). Alternative Metrics Initiative Phase 1 White Paper. Baltimore, MD. Retrieved from http://www.niso.org/apps/group_public/download.php/13809/

Altmetrics_project_phase1_white_paper.pdf3809/

Altmetrics_project_phase1_white_paper.pdf\&ei=Pw21VY6VIomE7QaRtZzoAQ\&usg=AF QjCNHTxIS80QjR1L3AHFCtxr1Ye6btaw

O'Leary, D. E. (2009). Downloads and citations in Intelligent Systems in Accounting, Finance and Management. Intelligent Systems in Accounting, Finance and Management, 16(1-2), $21-31$.

Rao, K. N., Sharma, R. K., Devi, S. G., \& Muralidhar, S. (2014). DESIDOC Bibliometric analysis of the Journal of Propulsion and Power (1985-2013). Journal of Library and Information Technology, 34(3), 271-276.

Roztocki, N., \& Weistroffer, H. R. (2011). Information technology success factors and models in developing and emerging economies. Information Technology for Development, 17(3), 
$163-167$.

Sanni, S. A., \& Zainab, A. N. (2010). Google scholar as a source for citation and impact analysis for a non-ISI indexed medical journal. Malaysian Journal of Library and Information Science, 15(3), 35-51.

Stillman, L., \& Linger, H. (2009). Community Informatics and Information Systems: Can They Be Better Connected? The Information Society, 25(4), 255-264.

Subramanyam, K. (1983). Bibliometric studies of research collaboration: A review. Journal of information Science, 6(1), 33-38.

Swain, C., K. Swain, D., \& Rautaray, B. (2013). Bibliometric analysis of Library Review from 2007 to 2011. Library Review, 62(8/9), 602-618.

Swain, D. K. (2013). Journal Bibliometric Analysis: A Case Study on Internet Research. Retrieved November 6, 2014, from http://digitalcommons.unl.edu/libphilprac/985/

Swain, D. K. (2014). Journal Bibliometric analysis: a case study on Quality assurance in education. International Multidisciplinary Research Journal, 4(4). Retrieved from http:// eprints.rclis.org/22997/1/4706.pdf

Swain, D. K., \& Panda, K. C. (2012). Journal of Intellectual Property Rights : A Bibliometric Study. Chinese Librarianship: an International Electronic Journal, 33(33), 1-12. Retrieved from www.iclc.us/cliej/cl33SP.pdf

Thelwall, M., \& Sud, P. (2016). Mendeley readership counts: An investigation of temporal and disciplinary differences. Journal of the Association for Information Science and Technology, 67(12), 3036-3050.

Van Biljon, J., Naudé, F., \& Lotriet, H. (2016). Citation measures for supporting scholarly impact in Community Informatics research. 13th Prato CIRN Conference, Engaging with Participation, Activism, and Technologies. 2-4 November 2016 (pp. 1-12). Monash Centre Prato, Italy: Centre for Community Informatics, Faculty of IT, Monash University. Retrieved from http://cirn.wikispaces.com/Conference+2016

Von Solms, R., \& Von Solms, B. (2016). Publish or Perish ... but where ? South African Computer Journal, 28(1), 1-11.

Wan, K., Anyi, U., Zainab, A. N., Anuar, N. B., \& Anyi, K. W. U. (2009). Bibliometric studies on single journals: A review. Malaysian Journal of Library and Information Science, 14(1), 17-55.

Zahedi, Z., Costas, R., \& Wouters, P. (2014). How well developed are altmetrics? A crossdisciplinary analysis of the presence of "alternative metrics" in scientific publications. Scientometrics, 101(2), 1491-1513. 


\section{Appendix}

Table 8: Top 20 JOCI articles ranked by article views

\begin{tabular}{|c|c|c|c|c|c|c|c|c|c|}
\hline Rank & Article Title & Year & $\begin{array}{c}\text { No of } \\
\text { authors }\end{array}$ & Authors & Affiliation & $\begin{array}{l}\text { Affiliated } \\
\text { country }\end{array}$ & $\begin{array}{l}\text { Article } \\
\text { views }\end{array}$ & GS & Mendeley \\
\hline 1 & $\begin{array}{l}\text { Social networks and Social Capital rethinking theory in community } \\
\text { informatics }\end{array}$ & 2008 & 2 & $\begin{array}{l}\text { K Williams } \\
\text { J. C. Durrance }\end{array}$ & $\begin{array}{l}\text { University of Illinois } \\
\text { University of Michigan }\end{array}$ & $\begin{array}{l}\text { USA } \\
\text { USA }\end{array}$ & 143425 & $105 \checkmark$ & $32 \checkmark$ \\
\hline 2 & Too old for technology? How the elderly of Lisbon use and perceive ICT & 2012 & 2 & $\begin{array}{l}\text { B.B. Neves } \\
\text { F. Amaro }\end{array}$ & $\begin{array}{l}\text { University of Lisbon } \\
\text { University of Lisbon }\end{array}$ & Portugal & 43828 & $50 \checkmark$ & $66 \checkmark$ \\
\hline 3 & $\begin{array}{l}\text { Guidelines for designing deliberative digital habitats: learning from e- } \\
\text { participation for open data initiatives }\end{array}$ & 2012 & 1 & F. De Cindio & Università degli Studi di Milano & Italy & 35337 & 23 & $27 \mathrm{v}$ \\
\hline 4 & $\begin{array}{l}\text { Sostenibilidad de proyectos de desarrollo con nuevas tecnologias: el caso de la } \\
\text { organizacion de regantes y su sistema de información en Huaral (Spanish) }\end{array}$ & 2007 & 1 & J.F. Bossio & Not indicated & Peru & 24595 & 4 & 12 \\
\hline 5 & $\begin{array}{l}\text { MyKnet.org: How Northern Ontario's First Nation Communities Made } \\
\text { Themselves At Home On The World Wide Web }\end{array}$ & 2009 & 3 & $\begin{array}{l}\text { P. Budka } \\
\text { B. Bell } \\
\text { A. Fiser }\end{array}$ & $\begin{array}{l}\text { University of Vienna } \\
\text { Univ. of Prince Edward Island } \\
\text { University of Toronto }\end{array}$ & $\begin{array}{l}\text { Austria } \\
\text { Canada } \\
\text { Canada }\end{array}$ & 23553 & 24 & 12 \\
\hline 6 & $\begin{array}{l}\text { Stakeholders' perceptions of the impact of a Global System for Mobile } \\
\text { Communication on Nigeria's rural economy: Implication for an emerging } \\
\text { communication Industry }\end{array}$ & 2007 & 4 & $\begin{array}{l}\text { T. Adeyinka } \\
\text { J.O. Ajiboye } \\
\text { A.O Emmanuel } \\
\text { J.I. Wojuade }\end{array}$ & $\begin{array}{l}\text { University of Botswana } \\
\text { University of Botswana } \\
\text { University of Ibadan } \\
\text { University of Ibadan }\end{array}$ & $\begin{array}{c}\text { Botswana } \\
\text { Botswana } \\
\text { Nigeria } \\
\text { Nigeria }\end{array}$ & 23390 & 12 & 9 \\
\hline 7 & $\begin{array}{l}\text { The role of social entrepreneurs in deploying ICTs for youth and community } \\
\text { development in South Africa }\end{array}$ & 2009 & 1 & C. J. Evoh & New School University & USA & 23255 & 9 & 11 \\
\hline 8 & $\begin{array}{l}\text { This is what modern deregulation looks like : co-optation and contestation in } \\
\text { the shaping of the UK's Open Government Data Initiative }\end{array}$ & 2012 & 1 & J. Bates & $\begin{array}{l}\text { Manchester Metropolitan } \\
\text { University }\end{array}$ & UK & 22469 & $68 \mathrm{v}$ & $52 \checkmark$ \\
\hline 9 & $\begin{array}{l}\text { Call Centres and their Role in E-governance: A Developing Country } \\
\text { Perspective }\end{array}$ & 2008 & 2 & $\begin{array}{l}\text { S. As-Saber } \\
\text { K. Hossain }\end{array}$ & $\begin{array}{l}\text { Monash University } \\
\text { Oxfam }\end{array}$ & $\begin{array}{c}\text { Australia } \\
\text { Bangladesh }\end{array}$ & 22269 & 4 & 10 \\
\hline 10 & $\begin{array}{l}\text { Anytime? Anywhere?: Reframing Debates Around Community and Municipal } \\
\text { Wireless Networking }\end{array}$ & 2008 & 1 & L. Forlano & Columbia University & USA & 19201 & $35 \checkmark$ & 21 \\
\hline 11 & $\begin{array}{l}\text { The Potential And Limits Of Mobile Phone For Development In Africa: Top- } \\
\text { Down-Meets-Bottom-Up Partnering }\end{array}$ & 2012 & 2 & $\begin{array}{l}\text { L. Hosman } \\
\text { E. Fife }\end{array}$ & $\begin{array}{l}\text { Illinois Institute of Technology } \\
\text { University of Southern } \\
\text { California }\end{array}$ & $\begin{array}{l}\text { USA } \\
\text { USA }\end{array}$ & 19072 & 3 & 11 \\
\hline 12 & $\begin{array}{l}\text { Towards participatory action design research : adapting action research and } \\
\text { design science research methods for urban informatics }\end{array}$ & 2011 & 2 & $\begin{array}{l}\text { M. Bilandzic } \\
\text { J. Venable }\end{array}$ & $\begin{array}{l}\text { Queensland University of } \\
\text { Technology, Brisbane } \\
\text { Curtin University, Perth }\end{array}$ & Australia & 18689 & $38 \mathrm{v}$ & $50 \checkmark$ \\
\hline 13 & $\begin{array}{l}\text { Unintended Behavioural Consequences of Publishing Performance Data: Is } \\
\text { More Always Better? }\end{array}$ & 2012 & 2 & $\begin{array}{l}\text { S. McGinnes } \\
\text { K.M. Elandy }\end{array}$ & $\begin{array}{l}\text { Trinity College } \\
\text { Trinity College }\end{array}$ & $\begin{array}{l}\text { Ireland } \\
\text { Ireland }\end{array}$ & 18049 & 8 & 19 \\
\hline
\end{tabular}




\begin{tabular}{|c|c|c|c|c|c|c|c|c|c|}
\hline 7 & $\begin{array}{l}\text { Towards participatory action design research : adapting action research } \\
\text { and design science research methods for urban informatics }\end{array}$ & 2011 & 2 & $\begin{array}{l}\text { M. Bilandzic } \\
\text { J. Venable }\end{array}$ & $\begin{array}{l}\text { Queensland Univ. of Technology } \\
\text { Curtin University }\end{array}$ & $\begin{array}{l}\text { Australia } \\
\text { Australia }\end{array}$ & 50 & $38 \checkmark$ & $18689 \checkmark$ \\
\hline 8 & $\begin{array}{l}\text { Social Impact and Diffusion of Telecenter Use: A Study from the } \\
\text { Sustainable Access in Rural India Project }\end{array}$ & 2006 & 2 & $\begin{array}{l}\text { R. Kumar } \\
\text { M.L. Best. }\end{array}$ & $\begin{array}{l}\text { Massachusetts Inst. of Technology } \\
\text { Georgia Institute of Technology }\end{array}$ & $\begin{array}{l}\text { USA } \\
\text { USA }\end{array}$ & 42 & $88 \mathrm{v}$ & 5684 \\
\hline 9 & $\begin{array}{l}\text { Is Community Informatics good for communities? Questions } \\
\text { confronting an emerging field }\end{array}$ & 2005 & 1 & R. Stoecker & University of Toledo & USA & 40 & $87 \checkmark$ & 4548 \\
\hline 10 & $\begin{array}{l}\text { A Research Design to Build Effective Partnerships between City } \\
\text { Planners, Developers, Government and Urban Neighbourhood } \\
\text { Communities }\end{array}$ & 2006 & 2 & $\begin{array}{l}\text { M. Foth } \\
\text { B. Adkins }\end{array}$ & Queensland Univ. of Technology & Australia & 35 & 30 & 5561 \\
\hline 11 & $\begin{array}{l}\text { Building community social capital: The potential and promise of } \\
\text { information and communications technologies }\end{array}$ & 2004 & 2 & $\begin{array}{l}\text { K.E. Pigg } \\
\text { L. D. Crank }\end{array}$ & $\begin{array}{l}\text { University of Missouri } \\
\text { University of Missouri }\end{array}$ & $\begin{array}{l}\text { USA } \\
\text { USA }\end{array}$ & 32 & $134 \checkmark$ & 12851 \\
\hline 12 & $\begin{array}{l}\text { Social networks and Social Capital rethinking theory in community } \\
\text { informatics }\end{array}$ & 2008 & 2 & $\begin{array}{l}\text { K Williams } \\
\text { J. C. Durrance }\end{array}$ & $\begin{array}{l}\text { University of Illinois } \\
\text { University of Michigan }\end{array}$ & $\begin{array}{l}\text { USA } \\
\text { USA }\end{array}$ & 32 & $105 \checkmark$ & $143425 \checkmark$ \\
\hline 13 & A review on mHealth research in developing countries & 2013 & 3 & $\begin{array}{l}\text { W. Chigona } \\
\text { M. Nyemba-Mudenda } \\
\text { A.S. Metfula }\end{array}$ & $\begin{array}{l}\text { University of Cape Town } \\
\text { University of Cape Town } \\
\text { University of Cape Town }\end{array}$ & $\begin{array}{l}\text { South Africa } \\
\text { South Africa } \\
\text { South Africa }\end{array}$ & 32 & 15 & 8276 \\
\hline 14 & $\begin{array}{l}\text { An Interpretivist Case Study of a South African Rural Multi-Purpose } \\
\text { Community Centre }\end{array}$ & 2005 & 2 & $\begin{array}{l}\text { J-P. Van Belle } \\
\text { J. Trusler }\end{array}$ & $\begin{array}{l}\text { University of Cape Town } \\
\text { University of Cape Town }\end{array}$ & $\begin{array}{l}\text { South Africa } \\
\text { South Africa }\end{array}$ & 28 & $35 \checkmark$ & 5647 \\
\hline 15 & $\begin{array}{l}\text { The value of Community Informatics to participatory urban planning and } \\
\text { design: a case-study in Helsinki }\end{array}$ & 2010 & 2 & $\begin{array}{l}\text { J.C. Saad-Sulonen } \\
\text { L. Horelli }\end{array}$ & $\begin{array}{l}\text { Aalto University } \\
\text { Aalto University }\end{array}$ & $\begin{array}{l}\text { Finland } \\
\text { Finland }\end{array}$ & 28 & 29 & 9499 \\
\hline 16 & Sustaining Community Access to Technology: Who should pay and why & 2005 & 2 & $\begin{array}{l}\text { V.N. Rideout } \\
\text { A.J. Reddick }\end{array}$ & $\begin{array}{l}\text { University of New Brunswick } \\
\text { University of New Brunswick }\end{array}$ & $\begin{array}{l}\text { Canada } \\
\text { Canada }\end{array}$ & 27 & $48 \mathrm{v}$ & 3312 \\
\hline 17 & $\begin{array}{l}\text { Some perspectives on understanding the adoption and implementation of } \\
\text { ICT interventions in developing countries }\end{array}$ & 2007 & 3 & $\begin{array}{l}\text { M. Ashraf } \\
\text { P. Swatman } \\
\text { J. Hanisch }\end{array}$ & $\begin{array}{l}\text { University of South Australia } \\
\text { University of South Australia } \\
\text { University of South Australia }\end{array}$ & $\begin{array}{l}\text { Australia } \\
\text { Australia } \\
\text { Australia }\end{array}$ & 27 & 20 & 9284 \\
\hline 18 & $\begin{array}{l}\text { Guidelines for designing deliberative digital habitats: learning from e- } \\
\text { participation for open data initiatives }\end{array}$ & 2012 & 1 & F. De Cindio & Università degli Studi di Milano & Italy & 27 & 23 & $35337 \checkmark$ \\
\hline 19 & $\begin{array}{l}\text { Mapping the Virtual in Social Sciences: On the Category of "Virtual } \\
\text { Community" }\end{array}$ & 2006 & 2 & $\begin{array}{l}\text { S. Proulx } \\
\text { G. Latzko-Toth }\end{array}$ & $\begin{array}{l}\text { Université du Québec } \\
\text { Université du Québec }\end{array}$ & $\begin{array}{l}\text { Canada } \\
\text { Canada }\end{array}$ & 26 & 12 & 4955 \\
\hline 20 & $\begin{array}{l}\text { Inside the "People of the Wheelbarrows": participation between online } \\
\text { and offline dimension in the post-quake social movement }\end{array}$ & 2010 & 2 & $\begin{array}{l}\text { M. Farinosi } \\
\text { E. Trere }\end{array}$ & $\begin{array}{l}\text { University of Udine } \\
\text { University of Udine }\end{array}$ & $\begin{array}{l}\text { Italy } \\
\text { Italy }\end{array}$ & 26 & 28 & 11299 \\
\hline
\end{tabular}




\begin{tabular}{|c|c|c|c|c|c|c|c|c|c|}
\hline 14 & $\begin{array}{l}\text { The Rhetoric of Transparency and its Reality: Transparent Territories, Opaque } \\
\text { Power and Empowerment }\end{array}$ & 2012 & 1 & B. Raman & French Institute at Pondicherry & India & 17352 & 13 & 15 \\
\hline 15 & $\begin{array}{l}\text { La Promocion de las TIC para el Desarrollo y los Pueblos Indigenas: } \\
\text { Extension o Comunicación? (Spanish) }\end{array}$ & 2007 & 2 & $\begin{array}{l}\text { S.M. Urquiaga } \\
\text { E.H. Velazquez }\end{array}$ & Not indicated & Mexico & 16543 & 3 & 8 \\
\hline 16 & $\begin{array}{l}\text { Digital technology access and use among socially and economically } \\
\text { disadvantaged groups in South Australia }\end{array}$ & 2010 & 3 & $\begin{array}{l}\text { L.A. Newman } \\
\text { K. Biedrzycki } \\
\text { F. Baum }\end{array}$ & $\begin{array}{l}\text { Flinders University } \\
\text { Flinders University } \\
\text { Flinders University }\end{array}$ & $\begin{array}{l}\text { Australia } \\
\text { Australia } \\
\text { Australia }\end{array}$ & 16280 & 24 & 21 \\
\hline 17 & $\begin{array}{l}\text { Economic and social empowerment of women through ICT: a case study of } \\
\text { Palestine }\end{array}$ & 2009 & 1 & K. S. Rabayah & Arab American University & Palestine & 15501 & 5 & 1 \\
\hline 18 & $\begin{array}{l}\text { Towards Place-peer community and civic bandwidth: a case study in } \\
\text { community wireless networking }\end{array}$ & 2008 & 1 & H Hye-Na Cho & Hallym University & Korea & 15069 & 17 & 14 \\
\hline 19 & $\begin{array}{l}\text { E-Governance in the Developing World in Action: The case of districtNet in } \\
\text { Uganda }\end{array}$ & 2008 & 2 & $\begin{array}{l}\text { A de Jager } \\
\text { V. van Reijswoud }\end{array}$ & $\begin{array}{l}\text { International Institute for } \\
\text { Communication and } \\
\text { Development } \\
\text { Divine Word University }\end{array}$ & $\begin{array}{l}\text { Netherlands } \\
\text { Papua New } \\
\text { Guinea }\end{array}$ & 14722 & 15 & 8 \\
\hline 20 & $\begin{array}{l}\text { From associations to info-sociations: civic associations \& ICTs in two Asian } \\
\text { cities }\end{array}$ & 2012 & 1 & D. Sadoway & University of Hong Kong & $\begin{array}{l}\text { Hong Kong, } \\
\text { China }\end{array}$ & 13204 & 10 & 9 \\
\hline
\end{tabular}

Table 9: Top 20 JOCI articles ranked by Mendeley Readership

\begin{tabular}{|c|c|c|c|c|c|c|c|c|c|}
\hline Rank & Article Title & Year & $\begin{array}{c}\text { No of } \\
\text { authors }\end{array}$ & Authors & Affiliation & $\begin{array}{l}\text { Affiliated } \\
\text { country }\end{array}$ & Mendeley & GS & $\begin{array}{l}\text { Article } \\
\text { views }\end{array}$ \\
\hline 1 & $\begin{array}{l}\text { Information kiosk based Indian E-Governance service delivery: Value } \\
\text { chain based measurement modelling }\end{array}$ & 2015 & 1 & H. Misra & $\begin{array}{l}\text { Institute of Rural Management } \\
\text { Anand }\end{array}$ & India & 85 & 1 & 1124 \\
\hline 2 & Community Informatics and Sustainability: Why Social Capital Matters & 2005 & 1 & L.E. Simpson & Queensland Univ. of Technology & Australia & 80 & $119 \checkmark$ & 7666 \\
\hline 3 & $\begin{array}{l}\text { Using a sustainable livelihoods approach to assessing the impact of ICTs } \\
\text { in development }\end{array}$ & 2006 & 2 & $\begin{array}{l}\text { S. Parkinson } \\
\text { R. Ramirez }\end{array}$ & $\begin{array}{l}\text { University of Guelph } \\
\text { University of Guelph }\end{array}$ & $\begin{array}{l}\text { Canada } \\
\text { Canada }\end{array}$ & 67 & $75 \checkmark$ & 10047 \\
\hline 4 & Too old for technology? How the elderly of Lisbon use and perceive ICT & 2012 & 2 & $\begin{array}{l}\text { B.B. Neves } \\
\text { F. Amaro }\end{array}$ & $\begin{array}{l}\text { University of Lisbon } \\
\text { University of Lisbon }\end{array}$ & $\begin{array}{l}\text { Portugal } \\
\text { Portugal }\end{array}$ & 66 & $50 \checkmark$ & $43828 \checkmark$ \\
\hline 5 & $\begin{array}{l}\text { This is what modern deregulation looks like : co-optation and } \\
\text { contestation in the shaping of the UK's Open Government Data Initiative }\end{array}$ & 2012 & 1 & J. Bates & Manchester Metropolitan Univ. & UK & 52 & $68 \mathrm{v}$ & $22469 \checkmark$ \\
\hline 6 & $\begin{array}{l}\text { Digital Inclusion Without Social Inclusion: The consumption of } \\
\text { information and communication Technologies (ICTs) in Homeless } \\
\text { Subculture in Central Scotland }\end{array}$ & 2006 & 1 & C.E. Bure & University of Edinburgh & Scotland & 50 & $53 \checkmark$ & 7679 \\
\hline
\end{tabular}


Table 10: Top 20 JOCI articles ranked by Google Scholar Citations

\begin{tabular}{|c|c|c|c|c|c|c|c|c|c|}
\hline Rank & Article Title & Year & $\begin{array}{c}\text { No of } \\
\text { authors }\end{array}$ & Authors & Affiliation & $\begin{array}{l}\text { Affiliated } \\
\text { Country }\end{array}$ & GS & Mendeley & $\begin{array}{c}\text { Article } \\
\text { views }\end{array}$ \\
\hline 1 & $\begin{array}{l}\text { Building community social capital: The potential and promise of } \\
\text { information and communications technologies }\end{array}$ & 2004 & 2 & $\begin{array}{l}\text { K.E. Pigg } \\
\text { L. D. Crank }\end{array}$ & $\begin{array}{l}\text { University of Missouri } \\
\text { University of Missouri }\end{array}$ & $\begin{array}{l}\text { USA } \\
\text { USA }\end{array}$ & 134 & $32 \checkmark$ & 12851 \\
\hline 2 & Community Informatics and Sustainability: Why Social Capital Matters & 2005 & 1 & L.E. Simpson & Queensland University of Technology & Australia & 119 & $80 \checkmark$ & 7666 \\
\hline 3 & $\begin{array}{l}\text { Cybercafes and their potential as Community Development Tools in } \\
\text { India }\end{array}$ & 2005 & 1 & A.M. Haseloff & Universität Augsburg & Germany & 113 & 23 & 4623 \\
\hline 4 & $\begin{array}{l}\text { Social networks and Social Capital rethinking theory in community } \\
\text { informatics }\end{array}$ & 2008 & 2 & $\begin{array}{l}\text { K Williams } \\
\text { J. C. Durrance }\end{array}$ & $\begin{array}{l}\text { University of Illinois } \\
\text { University of Michigan }\end{array}$ & $\begin{array}{l}\text { USA } \\
\text { USA }\end{array}$ & 105 & $32 \checkmark$ & $143425 \checkmark$ \\
\hline 5 & $\begin{array}{l}\text { Social Impact and Diffusion of Telecenter Use: A Study from the } \\
\text { Sustainable Access in Rural India Project }\end{array}$ & 2006 & 2 & $\begin{array}{l}\text { R. Kumar } \\
\text { M.L. Best. }\end{array}$ & $\begin{array}{l}\text { Massachusetts Institute of Technology } \\
\text { Georgia Institute of Technology }\end{array}$ & $\begin{array}{l}\text { USA } \\
\text { USA }\end{array}$ & 88 & $42 \checkmark$ & 5684 \\
\hline 6 & $\begin{array}{l}\text { Is Community Informatics good for communities? Questions } \\
\text { confronting an emerging field }\end{array}$ & 2005 & 1 & R. Stoecker & University of Toledo & USA & 87 & $40 \mathrm{r}$ & 4548 \\
\hline 7 & Crisis, Farming \& Community & 2005 & 2 & $\begin{array}{l}\text { C. Hagar } \\
\text { C. } \\
\text { Haythornthwaite }\end{array}$ & $\begin{array}{l}\text { University of Illinois at Urbana-Champaign } \\
\text { University of Illinois at Urbana-Champaign }\end{array}$ & $\begin{array}{l}\text { USA } \\
\text { USA }\end{array}$ & 77 & 7 & 5995 \\
\hline 8 & $\begin{array}{l}\text { Using a sustainable livelihoods approach to assessing the impact of ICTs } \\
\text { in development }\end{array}$ & 2006 & 2 & $\begin{array}{l}\text { S. Parkinson } \\
\text { R. Ramirez }\end{array}$ & $\begin{array}{l}\text { University of Guelph } \\
\text { University of Guelph }\end{array}$ & $\begin{array}{l}\text { Canada } \\
\text { Canada }\end{array}$ & 75 & $67 \checkmark$ & 10047 \\
\hline 9 & $\begin{array}{l}\text { This is what modern deregulation looks like : co-optation and } \\
\text { contestation in the shaping of the UK's Open Government Data Initiative }\end{array}$ & 2012 & 1 & J. Bates & Manchester Metropolitan University & UK & 68 & $52 \checkmark$ & $22469 \checkmark$ \\
\hline 10 & $\begin{array}{l}\text { Digital Inclusion Without Social Inclusion: The consumption of } \\
\text { information and communication Technologies (ICTs) in Homeless } \\
\text { Subculture in Central Scotland }\end{array}$ & 2006 & 1 & C.E. Bure & University of Edinburgh & Scotland & 53 & $50 \checkmark$ & 7679 \\
\hline 11 & Too old for technology? How the elderly of Lisbon use and perceive ICT & 2012 & 2 & $\begin{array}{l}\text { B.B. Neves } \\
\text { F. Amaro }\end{array}$ & $\begin{array}{l}\text { University of Lisbon } \\
\text { University of Lisbon }\end{array}$ & $\begin{array}{l}\text { Portugal } \\
\text { Portugal }\end{array}$ & 50 & $66 \checkmark$ & $43828 \checkmark$ \\
\hline 12 & Sustaining Community Access to Technology: Who should pay and why & 2005 & 2 & $\begin{array}{l}\text { V.N. Rideout } \\
\text { A.J. Reddick }\end{array}$ & $\begin{array}{l}\text { University of New Brunswick } \\
\text { University of New Brunswick }\end{array}$ & $\begin{array}{l}\text { Canada } \\
\text { Canada }\end{array}$ & 48 & $27 \sqrt{ }$ & 3312 \\
\hline 13 & $\begin{array}{l}\text { Open Government Data and the Right to Information: Opportunities and } \\
\text { Obstacles }\end{array}$ & 2012 & 1 & K. Janssen & University of Leuven & Belgium & 46 & 14 & 12992 \\
\hline 14 & The Impacts of Community Telecentres in Rural Colombia & 2006 & 4 & $\begin{array}{l}\text { F. Amariles } \\
\text { O.P. Paz } \\
\text { N. Russell } \\
\text { N. Johnson }\end{array}$ & $\begin{array}{c}\text { Cgiar } \\
\text { Colnodo, Administration } \\
\text { Cgiar } \\
\text { Cgiar }\end{array}$ & $\begin{array}{l}\text { Colombia } \\
\text { Colombia } \\
\text { Colombia } \\
\text { Colombia }\end{array}$ & 44 & 17 & 7774 \\
\hline 15 & $\begin{array}{l}\text { Towards participatory action design research : adapting action research } \\
\text { and design science research methods for urban informatics }\end{array}$ & 2011 & 2 & $\begin{array}{l}\text { M. Bilandzic } \\
\text { J. Venable }\end{array}$ & $\begin{array}{l}\text { Queensland Univ. of Technology } \\
\text { Curtin University }\end{array}$ & $\begin{array}{l}\text { Australia } \\
\text { Australia }\end{array}$ & 38 & $50 \checkmark$ & $18689 \checkmark$ \\
\hline
\end{tabular}




\begin{tabular}{|c|c|c|c|c|c|c|c|c|c|}
\hline 16 & $\begin{array}{l}\text { An Interpretivist Case Study of a South African Rural Multi-Purpose } \\
\text { Community Centre }\end{array}$ & 2005 & 2 & $\begin{array}{l}\text { J-P. Van Belle } \\
\text { J. Trusler }\end{array}$ & $\begin{array}{l}\text { University of Cape Town } \\
\text { University of Cape Town }\end{array}$ & $\begin{array}{l}\text { South } \\
\text { Africa } \\
\text { South } \\
\text { Africa }\end{array}$ & 35 & $28 \mathrm{r}$ & 5647 \\
\hline 17 & $\begin{array}{l}\text { Anytime? Anywhere?: Reframing Debates Around Community and } \\
\text { Municipal Wireless Networking }\end{array}$ & 2008 & 1 & L. Forlano & Columbia University & USA & 35 & 21 & $19201 \checkmark$ \\
\hline 18 & $\mathrm{n}$-Logue: The story of a rural service provider in India & 2004 & 3 & $\begin{array}{l}\text { A. Jhunjhunwala } \\
\text { A. Ramachandran } \\
\text { A. } \\
\text { Bandyopadhyay }\end{array}$ & $\begin{array}{c}\text { Indian Institute of Technology } \\
\text { TeNet } \\
\text { TeNet }\end{array}$ & $\begin{array}{l}\text { India } \\
\text { India } \\
\text { India }\end{array}$ & 32 & 14 & 6197 \\
\hline 19 & A Way Forward: Sustainable ICTs and Regional sustainability & 2005 & 4 & $\begin{array}{l}\text { G. Hearn } \\
\text { M. Kimber } \\
\text { J. Lennie } \\
\text { L. Simpson }\end{array}$ & $\begin{array}{l}\text { Queensland Univ. of Technology } \\
\text { Queensland Univ. of Technology } \\
\text { Queensland Univ. of Technology } \\
\text { Queensland Univ. of Technology }\end{array}$ & $\begin{array}{l}\text { Australia } \\
\text { Australia } \\
\text { Australia } \\
\text { Australia }\end{array}$ & 32 & 23 & 4022 \\
\hline 20 & $\begin{array}{l}\text { The Canadian Research Alliance for Community Innovation and } \\
\text { Networking (CRACIN): A research partnership and Agenda for } \\
\text { Community Networking in Canada }\end{array}$ & 2004 & 7 & $\begin{array}{l}\text { A. Clement } \\
\text { M. Gurstein } \\
\text { G. Longford } \\
\text { R. Luke } \\
\text { M. Moll } \\
\text { L.R. Shade } \\
\text { D. DeChief }\end{array}$ & $\begin{array}{l}\text { University of Toronto } \\
\text { New Jersey Institute of Technology } \\
\text { University of Toronto } \\
\text { University of Toronto } \\
\text { Ontario } \\
\text { Concordia University } \\
\text { Concordia University }\end{array}$ & $\begin{array}{l}\text { Canada } \\
\text { Canada } \\
\text { Canada } \\
\text { Canada } \\
\text { Canada } \\
\text { Canada } \\
\text { Canada }\end{array}$ & 31 & 15 & 4521 \\
\hline
\end{tabular}

